\title{
PENGARUH PEMBELAJARAN CONCEPT ATTAINMENT MODEL (CAM) TERHADAP KEMAMPUAN BERPIKIR KRITIS SISWA DI SMA NAHDATUL ULAMA (NU) PALEMBANG
}

\author{
Munir $^{1}$, Dini Afriyansyah ${ }^{2}$, Dewi Sundari ${ }^{3}$ \\ ${ }^{1,2,3}$ UIN Raden Fatah Palembang, Jl. Prof. K. H. Z. Abidin Fikri No 1 A KM 3.5, Palembang \\ e-mail:dewisundari27@yahoo.co.id
}

\begin{abstract}
This study aims to determine whether the learning model Concept Attainment Model (CAM) affect the Critical Thinking Ability of Students in SMA Nahdatul Ulama (NU) Palembang. This research uses quasi-experimental method (Quasi Eksperimental) with pretest-posttest control group design research design. Sampling is done by saturated sampling technique. The sample of this research is class X IPA 1 and class X IPA 2 in SMA Nahdatul Ulama (NU) Palembang. The results showed that there are differences in critical thinking ability of Animalia subject matter. Improvement Critical thinking ability can be seen on the result before using learning model that is Interpreter indicator, Analysis, Evaluation, Inference (Conclusion), Explanation (Explanation), Self-regulation is 36\%, 36\%, $37 \%, 41 \% 45 \%$, and $46 \%$. Whereas after using Learning Model on interpretation indicator, analysis, evaluation, inference (Conclusion), Explanation (Self Explanation), Self-regulation is $80 \%, 84 \%, 85 \%, 85 \%, 83 \%$, and $84 \%$. The results showed that this learning model can improve students' critical thinking ability. The results of statistical calculations obtained tcount $=3.474$ and ttable of 1.666 with $\mathrm{dk}$ (degrees of freedom) of 73 with a significant level of $5 \%$ so that tcount> ttable is 3.474> 1.666 and significance value $0.001>0.05$. Based on the hypothesis test, it can be concluded that the influence of learning model Concept Attainment Model to the critical thinking ability of students in SMA Nahdatul Ulama Palembang.
\end{abstract}

\section{Keywords: Concept Attaiment Model (CAM); Critical thinking}

\section{PENDAHULUAN}

Pendidikan nasional bertujuan untuk mengembangkan potensi peserta didik agar menjadi manusia yang beriman dan bertaqwa kepada Tuhan Yang Maha Esa, berahlak mulia, sehat, berilmu, cakap, kreatif, mandiri, dan menjadi warga negara yang demokratis serta bertanggung jawab. Pendidikan juga merupakan unsur yang paling penting dalam meningkatkan sumber daya manusia. Melalui pendidikan manusia akan menguasai ilmu pengetahuan yang dapat meningkatkan sumber daya manusia dan dapat menyelesaikan permasalahan yang dihadapi. Hal ini sejalan dengan undang-undang nomor 20 Tahun 2003 tentang sistem pendidikan nasional bahwa pendidikan nasional ber- fungsi mengembangkan kemampuan dan membentuk watak serta peradaban bangsa yang bermartabat dalam rangka mencedaskan kehidupan bangsa (UU No. 20 Tahun 2003).

Kemampuan berpikir kritis juga diamanahkan oleh kurikulum 2013 yang menekankan siswa untuk berpikir secara kritis dalam mengidentifikasi, memahami. memecahkan masalah, dan mengaplikasikan materi pembelajaran. Kenyataan di sekolah, pembelajaran Biologi belum banyak yang berorientasi ke arah pembiasaan dan peningkatan kecakapan keterampilan berpikir tingkat tinggi (berpikir kritis), tetapi masih menitik beratkan pada hasil belajar kognitif tingkat rendah. Siswa diharapkan menyerap 
informasi secara pasif dan kemudian mengingatnya pada saat mengikuti tes.

Rendahnya kemampuan berpikir kritis juga terjadi pada siswa di SMA Nahdatul Ulama (NU) Palembang. Berdasarkan hasil pengamatan dan observasi enam aspek berpikir kritis (Fascione, 2015) di SMA Nahdatul Ulama (NU) Palembang di dapatkan data bahwa kemampuan berpikir kritis peserta didik masih rendah, hal tersebut dapat di tunjukkan dengan hasil tes awal yang diberikan pada siswa kelas XI SMA Nahdatul Ulama Palembang yang terdiri dari 30 soal pilihan ganda dengan Indikator kemampuan Berpikir kritis. Berdasarkan hasil yang diperoleh dapat diketahui bahwa dari 25 siswa, kemampuan berpikir kritis tingkat tinggi siswa hanya sebesar $20 \%$, kemampuan berpikir kritis tingkat sedang $44 \%$ dan $36 \%$ kemampuan berpikir kritis siswa masih rendah. Berdasarkan tiap aspek berpikir kritis didapatkan aspek interprestasi $24 \%$, aspek analisis $40 \%$, aspek evaluasi $56 \%$, aspek kesimpulan 32\%, aspek penjelasan $48 \%$ dan aspek peraturan diri $24 \%$.

Berdasarkan hasil observasi PPLK (Praktik Pengalaman Lapangan Kependidikan) dan hasil wawancara langsung dengan guru Biologi SMA (NU) Palembang menjelaskan bahwa siswa mengalami kesulitan dalam memahami konsep Biologi. Wawancara juga dilakukan bersama siswa kelas XI SMA Nahdatul Ulama (NU) Palembang. Selain wawancara bersama guru mata pelajaran Biologi SMA Nahdatul Ulama (NU) Palembang, berdasarkan hasil observasi nilai pelajaran Biologi di kelas belum mencapai Kriteria Ketuntasan Minimum (KKM) yang ditetapkan yaitu dengan nilai 75. Tepatnya pada materi Animalia cenderung rendah karena kurang memahami dengan konsep yang berkaitan dengan penyelesaian soal. Untuk menumbuhkan suatu konsep dalam pelajaran, seorang guru perlu mengajarkan dalam konteks nyata dengan mengaitkannya terhadap lingkungan sekitar. Hal ini akan mampu mengembangkan kemampuan berpikir kritisnya terhadap materi yang akan di ajarkan. Oleh karena itu penerapan pembelajaran guru di kelas dapat dibuat secara bervariasi menggunakan model-model pembelajaran yang ada.

Penggunaan model pembelajaran yang tepat, merupakan waktu alternatif untuk mengatasi masalah rendahnya daya serap siswa terhadap pelajaran Biologi. Setiap model pembelajaran harus sesuai untuk mencapai suatu tujuan tertentu. Jadi untuk tujuan yang berbeda guru harus menggunakan teknik penyajian yang berbeda untuk mencapai tujuan pembelajaran. Salah satu model pembelajaran yang sesuai untuk meningkatkan kemampuan berpikir kritis siswa ialah model pencapian konsep (Concept Attainment Model). Menurut Bruner yang dikutip Dahar (1996), model percapaian konsep (Concept Attainment Model) di bangun berkaitan dengan studi berpikir siswa. Hal ini senada dengan pendapat Joyce, B., Weil, (2009) menyatakan bahwa, "model pembelajaran pencapaian konsep (Concept Attainment Model) mempertajam keterampilan berpikir dasar." Dari pernyataan Joyce tersebut menunjukan bahwa model pencapaian konsep di dalamnya terkandung pelajaran berpikir siswa. Dalam rangka mewujudkan tujuan pembelajaran maka perlu menumbuhkan keterampilan berpikir siswa khususnya keterampilan berpikir kritis mutlak diperlukan. Peserta didik yang telah "mencapai konsep" tidak hanya mampu menghapal sejumlah konsep yang telah dipelajarinya, tetapi ia juga harus mampu menerapkannya pada aspek lainnya dengan mengembangkan konsep berpikirnya (Martomidjojo dan Nuryani, 2011). 


\section{Model Concept Attainment Model}

Menurut Joyce dan Weil (2009) Struktur pengajaran atau Sintak model pencapaian konsep adalah tahap-tahap kegiatan dari model pembelajaran konsep. Model pembelajaran konsep memiliki tiga fase, yaitu:

a) Tahap Penyajian Data dan Identifikasi Konsep

Guru memberikan contoh-contoh kepada siswa, contoh tersebut merupakan data "contoh positif" dan "contoh negatif" konsep terpisah. Data tersebut dapat berupa kejadian, manusia, objek, cerita, gambar atau lainnya yang dapat dibedakan satu sama lain dan belum diberi nama konsep. Siswa diberitahu oleh guru mengenai contoh positif yang memiliki satu gagasan umum.

Tugas siswa adalah mengembangkan satu hipotesis tentang sifat atau ciri- ciri dari konsep tersebut dengan cara membandingkan sifat dan ciri dalam contoh positif dan negatif. Contoh-contoh disajikan dalam suatu instruksi yang telah diatur sebelumnya dan dilabeli dengan "Ya" atau "Tidak". Pada akhirnya, siswa diminta untuk menamai konsep-konsep mereka dan menyampaikan aturan-aturan atau definisi konsep menurut sifat yang paling esensial.

b.) Pengujian Pencapaian Konsep

Siswa menguji penemuan konsep mereka dengan cara mengidentifikasi secara tepat contoh-contoh tambahan yang tidak dilabeli dari konsep dan kemudian siswa membuat contoh-contoh menurut mereka. Langkah selanjutnya guru dan siswa mengoreksi contoh positif dan contoh negatif kemudian merevisi contoh mana saja yang benar, kemudian siswa mencari contoh lain yang sesuai dengan konsep.

b) Analisis Strategi Berpikir

Pada tahap analisis strategi berpikir, siswa mendeskripsikan pemikiran- pemikiran mereka, mendiskusikan peran sifat-sifat dan hipotesis serta mendiskusikan jenis dan ragam hipotesis. Siswa menganalisis strategistrategi berpikir mereka untuk mencapai konsep yang dimaksud. Strategi berpikir siswa bervariasi, ada yang mencoba dan mengkerucutkan konsep, dan ada pula yang memperluas konsep. Siswa diminta mengungkapkan alasan-alasan yang berkenan dengan membuat contoh tambahan, merumuskan konsep dengan kata-kata sendiri dan menjabarkan langkah penyelesaian suatu konsep.

\section{Indikator Kemampuan Berpikir Kritis}

Indikator kemampuan berpikir kritis yang digunakan dalam penelitian ini adalah indiator kemampuan berpikir kritis dari Facione (2015), antara lain Interpretation, analysis, evaluation, inference, explanation, serta self regulation. Interpretation adalah kemampuan dapat memahami dan mengekspresikan makna/ arti dari pemasalahan. Analysis adalah kemampuan dapat mengidentifikasi dan menyimpulkan hubungan antar pernyataan, pertanyaan, konsep, deskripsi, atau bentuk lainnya. Evaluation adalah kemampuan dapat mengakses kredibilitas pernyataan/representasi serta mampu mengakses secara logika hubungan antar pernyataan, deskripsi, pertanyaan, maupun konsep. Inference adalah kemampuan dapat mengidentifikasi dan mendapatkan unsurunsur yang dibutuhkan dalam menarik kesimpulan. Explanation adalah kemampuan dapat menetapkan dan memberikan alasan secara secara logis berdasarkan hasil yang diperoleh. Sedangkan indikator yang terakhir self regulation adalah kemampuan untuk memonitoring aktivitas kognitif seseorang, unsur-unsur yang digunakan dalam aktivitas menyelesaikan permasalahan, khususnya dalam menerapkan kemampuan dalam menganalisi dan mengevaluasi. 


\section{METODE PENELITIAN}

Penelitian ini dilaksanakan pada semester genap tahun ajaran 2016/2017, pada tanggal 24 April 2017 sampai dengan tanggal 8 Mei 2017 di SMA Nahdatul Ulama (NU) Palembang. Desain penelitian kuantitatif ini menggunakan metode Quasi Experimental Design (Eksperimen Semu). Bentuk desain yang akan digunakan pretest-posttest control group design di mana terdapat dua kelas yang terpilih secara random. Variabel dalam penelitian ini adalah Model pembelajaraN Concept Attaiment Model sebagai Variabel bebas dan Kemampuan Berpikir Kritis sebagai variable terikat.

Pada penelitian ini populasi yang diambil adalah siswa kelas X SMA Nahdatul Ulama (NU) Palembang tahun ajaran 2016/2017 yang berjumlah 75 siswa yang tersebar dalam 2 kelas. Sampel yang diambil dari populasi harus benar representatif (mewakili) (Sugiyono, 2014). Sampel Penelitian ini adalah siswa kelas X di SMA Nahdlatul Ulama Palembang. Teknik pengambilan sampel dalam penelitian ini dilakukan menggunakan teknik sampling jenuh. Karena semua populasi dijadikan sampel yaitu kelas X IPA 1 sebagai kelas eksperimen dan kelas X IPA 2 sebagai kelas kontrol.

Dalam penelitian ini dilakukan dengan beberapa tahapan adalah sebagai berikut: (1) Tahapan persiapan yaitu mempersiapkan Rencana Pelaksaan Pembelajaran (RPP) yang mengacu pada kegiatan, mempersiapkan media dan sumber pembelajaran. Selanjutnya membuat dan menyusun instrumen penelitian (insrument tes). Tahap pelaksanaan yaitu penelitian ini dilakukan selama 3 kali pertemuan pada kelas eksperimen menggunakan model pembelajaran Concept Attainment Model. (a). Memberikan tes awal (pre-test), (b). Memberikan perlakuan yaitu dengan cara menerapkan model pembelajaran Concept Attainment Model Tahap Pertama: Penyajian Data dan Identifikasi Konsep, Tahap Kedua: Pengujian Pencapaian Konsep, Tahap Ketiga: Analisis Strategi-Strategi Berpikir (c). Memberikan tes akhir (post-test).Adapun prosedur penelitian kelas kontrol adalah: (1). Tahap Persiapan: Pada tahap ini sama dengan yang dilakukan pada kelas eksperimen (2). Tahap pelaksanaan: Dalam pembelajaran kelas kontrol menggunakan model konvensional (diskusi, ceramah dan tanya jawab) dengan langkah-langkah sebagai berikut: (a) Memberikan tes awal (Pretest) (b) Memberikan perlakukan yaitu dengan cara menerapkan model konvensional (c) memberikan tes akhir (Post-test). (3). Tahap Akhir: pengumpulan data yang diperoleh selama penelitian berlangsung kemudian mengelolahnya, menganalisis, membahas, membuat hasil penelitian dan membuat kesimpulan.

\section{HASIL DAN PEMBAHASAN}

Teknik pengumpulan data dengan observasi digunakan jika penelitian berkenaan dengan perilaku manusia, proses kerja dan gejala-gejala alam (Sugiyono, 2015). Jumlah total soal tes yang digunakan dalam penelitian ini ialah sebanyak 30 soal. Soal-soal tes yang diberikan merupakan soal tes yang dapat mengukur ketercapaian kemampuan berpikir kritis siswa yang menurut Fascione. Data yang diperoleh dari lembar observasi dianalisis secara deskriptif untuk setiap siklusnya. Hasil analisis digunakan sebagai masukan perbaikan bagi siklus berikutnya.

\section{Uji Normalitas}

Uji normalitas data dalam penelitian ini dilakukan dengan menggunakan Uji Shapiro-Wilk dihitung dengan bantuan program SPSS 23. 


\section{Uji Homogenitas}

$\mathrm{H}_{0}: \mathrm{O}_{1}^{2}=\mathrm{O}_{2}^{2} \quad$ (Varian kedua kelas homogen)

$\mathrm{H}_{0}: \mathrm{O}_{1}^{2} \neq \mathrm{O}_{2}^{2}$ (Varian kedua kelas tidak homogen)

\section{Uji Hipotesis}

Untuk

$$
\text { menguji }
$$

hipotesis

menggunakan bantuan program SPSS 23.

Pada uji t ini, ada beberapa ketentuan yang dijadikan pedoman yaitu jika $t_{\text {hitung }}<t_{\text {tabel }}$ atau nilai signifikansi $>0,05$, maka $\mathrm{H}_{0}$ diterima dan jika $t_{\text {hitung }}>t_{\text {tabel }}$ atau nilai signifikansi $<0,05$ maka $\mathrm{H}_{0}$ ditolak (Gunawan, 2016).

\section{Normalitas Gain}

Gain adalah selisih nilai Pre-test dan post-test. Gain menunjukkan peningkatan penguasaan konsep siswa setelah dilakukan pembelajaran dilakukan oleh guru. $\mathrm{N}$-gain dianalisis uji normalitas, homogenitas, serta Uji-t dengan bantuan program SPSS 23. Rumus yang dilakukan untuk menghitung gain ternormalitas adalah:

$$
\mathrm{G}=\frac{T_{f}-T_{i}}{S_{i}-T}
$$

\section{HASIL DAN PEMBAHASAN}

Penelitian ini dilaksanakan di SMA NU Palembang pada tanggal 24 April 2017 sampai dengan 8 Mei 2017. Dari penelitian ini dilakukan dengan tiga tahap yaitu tahap persiapan, tahap pelaksanaan dan tahap evaluasi. Data hasil penelitian dianalisis untuk meninterprestasikan data yang telah terkumpul. Sekaligus menjawab hipotesis penelitian. Setelah dilakukan analisis akhir (pengujian hipotesis), maka perlu dilakukan pengujian prasyarat pada data yang telah diperoleh.

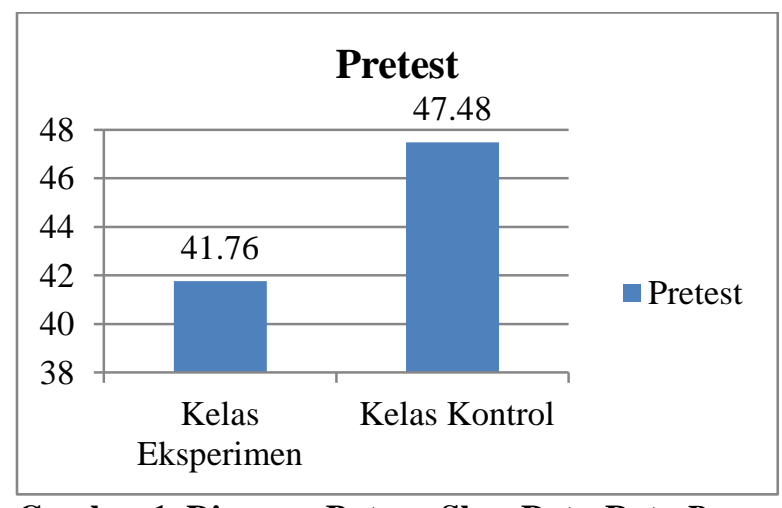

Gambar 1. Diagram Batang Skor Rata-Rata Pretest

Berdasarkan diagram batang di atas dapat dilihat rata-rata pretest kelas eksperimen adalah 41,76 dan kelas kontrol ada- lah 47,48 yang berarti nilai rata-rata pretest kelas kontrol lebih tinggi dibandingkan dengan kelas eksperimen.

\section{Uji Normalits}

Tabel 1 Hasil Uji Normalitas Pretest dengan Shapiro-Wilk

\begin{tabular}{lccc}
\hline \multirow{2}{*}{ Nilai } & \multicolumn{2}{c}{ Signifikan } & Keterangan \\
\cline { 2 - 3 } & Kelas Ekperimen & Kelas Kontrol & \\
\hline Pretest & $0,221>0,05$ & $0,118>0,05$ & Data berdistribusi Normal \\
\hline Posttest & $0,058>0,05$ & $0,120>0,05$ & Data berdistribusi Normal \\
\hline
\end{tabular}


Berdasarkan hasil uji normalitas yang telah didapatkan, dapat diketahui bahwa nilai uji normalitas Pretest untuk kelas eksperimen dan kelas kontrol yaitu sebesar 0, $221>0,05$ dan $0,118>0,05$, Sedangkan pada nilai uji normalitas Posttest untuk kelas eksperimen dan kelas kontrol yaitu sebesar 0,058>0,05 dan $0,120>0,05$, maka dengan dasar pengambilan keputusan dalam uji normalitas shapiro-Wilk, kedua data dinyatakan berdistribusi normal.

\section{Uji Homogenitas}

Tabel 2 Hasil Uji Pretest Levene Statistic Test of Homogeneity of Variances

\begin{tabular}{lcccc}
\hline Nilai & Levene Statistic & df 1 & df 2 & Sig \\
\hline Pretest & 2,017 & 1 & 73 & 0,160 \\
\hline Posttest & $\mathbf{0 , 5 9 0}$ & 1 & 73 & 0,445 \\
\hline
\end{tabular}

Berdasarkan hasil uji homogenitas yang telah didapatkan diketahui bahwa nilai signifikan uji homogenitas pretest untuk kelas eksperimen dan kelas kontrol yaitu sebesar $0,160>0,05$, sedangkan uji homogenitas posttest untuk kelas eksperi- men dan kelas kontrol yaitu sebesar 0,445 > 0,05 maka dengan dasar pengambilan keputusan dalam uji homogenitas Levene Statistic, dapat dinyatakan bahwa kedua kelompok memiliki varian yang sama atau homogen.

\section{Hipotesis}

Tabel 3. Hasil uji Pretest-Posttest dengan Uji-t

\begin{tabular}{|c|c|c|c|c|c|c|}
\hline Nilai & Kelas & Mean & $\mathbf{t}_{\text {hitung }}$ & $\mathbf{t}_{\text {tabel }}$ & Sig & Kesimpulan \\
\hline \multirow{2}{*}{ Pretest } & Eksperimen & 41,76 & \multirow{2}{*}{$-1,926$} & \multirow{2}{*}{1,666} & \multirow{2}{*}{0,001} & $\mathrm{H}_{\mathrm{a}}$ ditolak \\
\hline & Kontrol & 47,48 & & & & $\mathrm{H}_{0}$ diterima \\
\hline \multirow{2}{*}{ Posttest } & Eksperimen & 83,55 & \multirow{2}{*}{3,474} & \multirow{2}{*}{1,666} & \multirow{2}{*}{0,001} & $\mathrm{H}_{\mathrm{a}}$ ditolak \\
\hline & Kontrol & 75,16 & & & & $\mathrm{H}_{0}$ diterima \\
\hline
\end{tabular}

Berdasarkan tabel di atas untuk nilai pretest pada kelas eksperimen dan kontrol diperoleh bahwa nilai $t_{\text {hitung }}$ sebesar $-1,926$ berdasarkan tabel distribusi, nilai $t_{\text {tabel }}$ untuk $\mathrm{df}=73$ sebesar 1,666 dan nilai signifikansi $0,058>0,05$. Sedangkan nilai posttest pada kelas eksperimen dan kontrol diperoleh bahwa nilai $t_{\text {hitung }}$ sebesar 3,474 berdasarkan tabel distribusi, nilai $t_{\text {tabel }}$ untuk df $=73$ sebesar 1,666 dan nilai signifikansi 0,001 < 0,05 . Dengan nilai $t_{\text {hitung }}>t_{\text {tabel, }}$ maka sesuai dengan dasar pengambilan keputusan dalam uji-t Independent sample, dapat disimpulkan bahwa $\mathrm{H}_{0}$ di terima dan $\mathrm{H}_{\mathrm{a}}$ ditolak. Keputusan yang diperoleh adalah terima $\mathrm{H}_{0}$, yang artinya siswa pada kelas eksperimen dan kelas kontrol pada Pokok Bahasan Animalia tidak berbeda signifikan atau pengetahuan awal yang sama.

\section{Nilai N-gain}

Berdasarkan tabel diatas, dapat dilihat $\mathrm{N}$-gain kelas Eksperimen adalah 0,74 yang berarti masuk dalam kategori tinggi. Sedangkan, dapat dilihat $\mathrm{N}$-gain kelas kontrol adalah adalah 0,59 yang berarti masuk dalam kategori sedang. Maka dapat disimpulkan bahwa $\mathrm{N}$-gain pada kelas eksperimen lebih tinggi dibandingkan dengan $\mathrm{N}$-gain pada kelas kontrol. Perbandingan hasil data N-gain kelas eksperimen dengan kelas kontrol dapat dilihat pada diagram batang di bawah ini: 


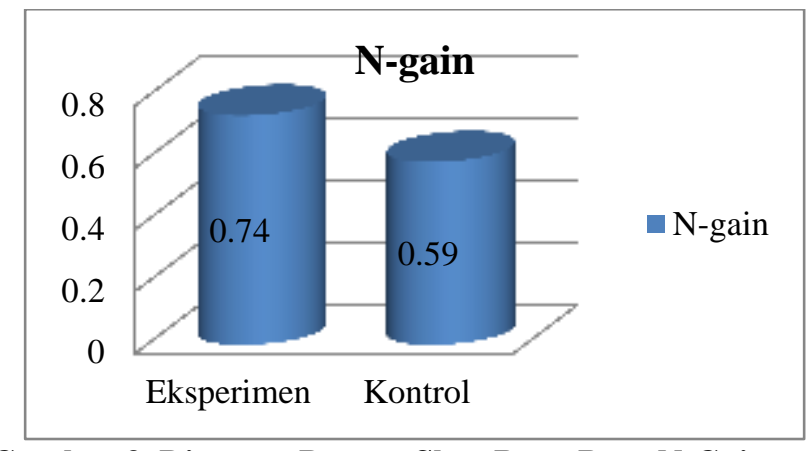

Gambar 3. Diagram Batang Skor Rata-Rata N-Gain

Analisis Kemampuan Berpikir Kritis Siswa

Adapun hasil analisis kemmapuan berpikir kritis siswa melalui pendeskripsian kemampuan kognitif yang digunakan dalam penyelesaian soal antara kelas eksperimen dan kelas kontrol bedasarkan kemampuan berpikir kritis dari persentase $\mathrm{N}$-gain dari hasil pretest dan posttest disajikan dalam diagram batang di bawah ini:

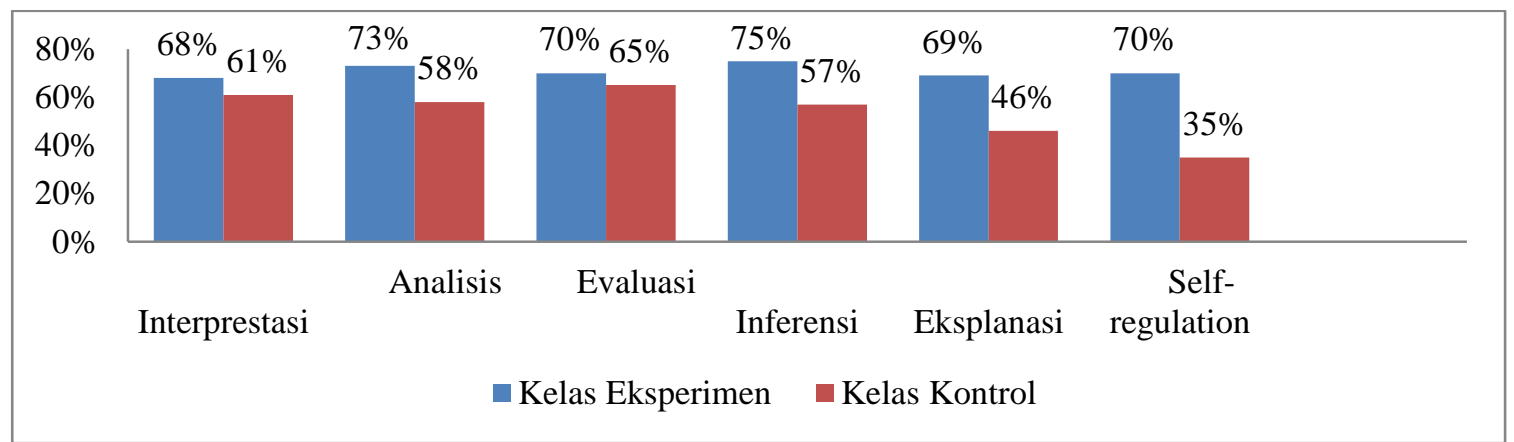

Gambar 4. Diagram Batang N-gain Pretest dan Posttest Kelas Eksperimen dan Kelas Kontrol

Berdasarkan diagram batang di atas dapat diketahui bahwa pesentase setiap indikator kemampuan berpikir kritis, yaitu didapatkan interprestasi analisis, evaluasi, kesimpulan penjelasan dan pengaturan diri, antara kelompok eksperimen dan kontrol seperti ditunjukkan pada diagram di atas. Untuk kelas eksperimen \% $\mathrm{N}$-gain kemampuan berpikir kritis pada indikator interprestasi, analisis, evaluasi, kesimpulan, penjelasan dan pengaturan diri, secara berurutan adalah $68 \%, 73 \%, 70 \%, 75 \%$, $69 \%, 70 \%$. Pada kelas kontrol persentase Ngain kemmapuan berpikir kritis pada indikator interprestasi, analisis, evaluasi, kesimpulan penjelasan dan pengaturan diri secara berurutan adalah 61\%, 58\%, 65\%, $57 \%, 46 \%, 35 \%$. Peningkatan kemampuan berpikir kritis yang paling tinggi yang dicapai kelas eksperimen terjadi pada indikator inferensi (kesimpulan) masingmasing berurutan sebesar $75 \%$. Sedangkan kelas kontrol terjadi pada indikator soal evaluasi masing-masing secara berurutan sebesar $65 \%$. Sedangkan menurut pendapat Liliasari (2003), mengemukakan bahwa kemampuan berpikir kritis harus ditanamkan pada anak pada usia 11 tahun ke atas anak berpikir reflektif menggunakan asumsi dan hipotesis. Dan kemampuan berpikirnya tidak lagi terkait tetapi menjangkau waktu lampau dan masa depan.

\section{Pembahasan}

Berdasarkan hasil analisis penelitian maka dapat diketahui bahwa nilai pretest pada kelas ekperimen dan kelas kontrol, setelah dilakukan uji normalitas dan uji homogenitas serta uji-t dengan bantuan 
program SPSS 23 hasil yang didapat adalah $\mathrm{t}_{\text {hitung }}=3,474>\mathrm{t}_{\text {tabel }}=1,666$ maka $\mathrm{H}_{0} \mathrm{di}$ tolak dan $\mathrm{H}_{\mathrm{a}}$ diterima, yang artinya siswa pada kelas eksperimen dan kelas kontrol pada materi perubahan lingkungan tidak berbeda signifikan atau mempunyai pengetahuan awal yang sama. Tidak adanya perbedaan hasi pretest di sini dapat diketahui dari proses kegiatan sisa mengajarkan soal pretest hal ini bisa terjadi karena mereka belum mempelajari materi yang mereka kerjakan. Akan tetapi, jika siswa tersebut bisa mengaitkan materi yang ada di dalam soal pretest tersebut dengan pengetahuan yang telah mereka dapat sebelumnya maka siswa akan bisa menjawab soal tersebut tanpa harus bertanya kepada temannya. Menurut Pantiwati (2015), menyatakan bahwa pada masa sekarang, peserta didik cenderung duduk diam mendengarkan tanpa mampu mengembangkan informasi yang diperoleh atau berdiskusi, pada dasarnya siswa mempunyai keterampilan berpikir kritis dalam belajar misalnya keterampilan bertanya, hipotesis, klasifikasi, observasi (pengamatan) dan interprestasi.

Nilai posttest pada kelas eksperimen dan kelas kontrol, setelah dilakukan uji normlaitas, uji homogenitas serta uji-t dengan bantuan SPSS 23 hasil yang didapat adalah $t_{\text {hitung }}=3,474<t_{\text {tabel }}=1,666$ maka $\mathrm{H}_{0}$ diterima dan $\mathrm{H}_{\mathrm{a}}$ ditolak, yang artinya kelas eksperimen dan kelas kontrol pada materi sistem peredaran darah manusia berbeda signifikan atau mempunyai pengetahuan yang berbeda. Concept Attaiment Model merupakan suatu model pembelajaran yang didesain untuk mengembangkan kemampuan berpikir induktif, tetapi juga untuk menganalisis dan mengembangkan konsep pada diri siswa (Joyce dan Weil, 2009).

$\mathrm{N}$-gain (selisih antara nilai posttest dan pretest), yang menunjukkan peningkatan kemampuan berpikir kritis siswa setelah pembeljaran. Rata-rata N-gain pada kelas eksperimen adalah 0,74 yang termasuk kategori tinggi, sedangkan pada kelas kontrol 0,59 yang termasuk kategori sedang. Dapat disimpulkan bahwa peningkatan kemampuan berpikir kritis lebih tinggi di kelas eksperimen di bandingkan kelas kontrol. Hal ini sejalan dengan penelitian Prayitno (2014), bahwa model Concept Attainment lebih baik dari pada model konvensional, lebih efektif dalam hal pencapian konsep dalm lebih efektif dalam retensi konsep dari pada model konvensional.

Berdasarkan uraian di atas menunjukkan bahwa pelaksanaan ynag berbeda menyebabkan terjadinya hasil akhir yang berbeda anatar kelompok eksperimen yang diajarkan menggunakan model concept attainment dengan kelompokmkontrol yang menggunakan model konvensional (diskusi, ceramah, dan tanya jawab). Dengan demikian , ternyata terbukti bahwa model concept Attainment berpengaruh tehadap kemmapuan berpikir kritis siswa dalam materi animalia di kelas X SMA Nahdatul Ulama (NU) Palembang.

\section{SIMPULAN DAN SARAN}

Berdasarkan hasil penelitian ini dapat disimpulkan bahwa nilai $t_{\text {hitung }}=3,474>t_{\text {tabel }}$ = 1,666 maka $\mathrm{H}_{\mathrm{a}}$ diterima yan berbunyi: ada pengaruh model pembeljaran Concept Attainment Model terhadap kemampuan berpikir kritis siswa pada materi animalia kelas X SMA Nahdatul Ulama (NU) Palembang.

\section{RUJUKAN}

Dahar, R.W. (1996). Teori-Teori Belajar. Jakarta: Erlangga.

Dimyanti dan Mujiono. (2009). Belajar dan Pembelajaran. Jakarta: Rineka Cipta.

Facione, P.A. (2015). Critical Thinking What It Is and Why It Counts. Insight Assessment. 
Joyce, B., Weil, M., dan Calhoun, E. (2009). Models of Teaching. $8^{\text {th }}$ Ed. Diterjemahkan oleh Ahmad F dan Ateilla. 2010. Pustaka Pelajar, Yogyakarta.

Liliasari, 2003, "Peningkatan Mutu Guru dalam Keterampilan Berpikir Tingkat tinggi melalui model Pembelajaran kapita selekta Kimia Sekolah lanjutan. Jurnal Kimia.

Martomidjojo. R., dan Nuryani Y. R., (2011). Pembelajaran Biologi Sel Berbasis Keterampilan Berfikir Kritis menggunakan Concept Attainment Model. Skripsi. Upi Bandung. Seminar Nasional VIII pendidikan Biologi.

Prayitno, A. B. (2014). Pembelajaran Biologi dengan Concept Attaiment Model menggunakan Teknik Vee Diagram dan
Concept Map ditinjau dari kemampuan Berpikir Kritis dan Penalaran Ilmiah. Jurnal Inkuiri. Jurnal Fkip. Universitas Negeri Semarang. Vol 3. No 2. ISSN: 2252-7893.

Priatna. (2013). Kemapuan Penalaran dan Pemahaman Matematika Siswa Kelas III SLTP di Kota Bandung. Disertasi Bandung: SPs Upi.

Pantiwati, Y. (2015). Peningkatan Kemampuan Berpikir Kritis dengan Pembeljaran Berbasis Scientific Approach Siswa Kelas X SMA Panjura Malang. Jurnal pendidikan biologi indonesia. Pendidikan Biologi FKIP Universitas Muhammadiyah Malang. Vol 1. No 2. ISSN: 2442-3750.

Sugiyono. (2013). Statistika untuk Penelitian. Bandung Alfabeta. 